\title{
Alluvial Diamond Potential of Paleo-drainage systems in the Headwaters of the São Francisco River, Minas Gerais, Brazil.
}

\author{
Pereira, R. S. ', Wheelock, G. ${ }^{2}$, Bizzi, L. ', Silva, H. ', Leite, A. '
}

1. Sopemi - Pesquisa e Exploração de Minérios S/A. Strategic Services Dept. SIA Trecho 2, lote 1591. Brasilia, DF, Brazil. 2. Namaqualand Mines, De Beers Consolidated Mines Ltd. Kleinzee 8282.

Sedimentological, structural and morphologic interpretations using satellite imagery, aerial photographs, airmag and gravimetric data, plus field observations provide evidence for an extensive paleodrainage system situated between the present-day São Francisco and Piumhi river valleys. The possibility that such paleodrainage system was somehow linked to the present-day São Francisco river valley in the past was explored by SOPEMI because of the presence of numerous diamond digging areas (which have been mined over the past 60 years) along this part of the São Francisco river.

The present-day São Francisco river valley is controlled by ancient systems of faults oriented east-west and rejuvenated since Mesozoic time. The paleodrainage was controlled by a combination of this valley and a NW-SE trending group of thrust faults originated in the Upper Proterozoic, during the Brasiliano Orogenesis, and rejuvenated in the Mesozoic (attached map). Following the first order delineation of the paleodrainage system using remote sensing techniques, both drilling and geophysical data have been used to assess lateral \& depth extension of the paleo river channels and sedimentological techniques were used to assess their economic significance.

The proximal end of the São Francisco river (Locality 1) has evidence for a high gradient, fast flowing river that generated an angular grit composed of fragments from the footwall Canastra quartzite. Beneath the Casca D'Antas waterfall (which marks today's head waters of the São Francisco river; Locality 2), there is evidence for a marked drop in elevation which affected the boulder generation capacity of the river system and led to the formation of a trap site for diamonds. An uplift during rejuvenation (in the Tertiary?) of a WNW-ESE fault system led to erosion of the Canastra foot wall and generation of a valley with a barren reach. with no generation of alluvial deposits up to Locality 4 (Digging $\mathrm{n}^{\circ} 1$ ). At Locality 4 deposition occurred as a result of repeated base level reactivations. Evidence for one of such events is preserved in the form of a high level fluvial terrace, some $26 \mathrm{~m}$ above the present day drainage. This deposit, which is the highest terrace level in the study area, has a highly immature texture and was generated mainly at the expense of materials collected between the waterfall (Locality 2) and Locality 4 . A second gravel unit is seen some $11 \mathrm{~m}$ below the highest level terrace, along the same profile. The internal fabric of such second gravel unit is more ordered than the one above. At an even lower elevation, at the same Locality 4, a third gravel unit occurs. This third gravel unit, which is situated ca $8 \mathrm{~m}$ above the present day river level, is a normally graded channel deposit which comprises of smaller framework clasts set in a grit matrix almost devoid of clay. Both of the lower elevation deposits (i.e. second and third gravel levels) are younger derivatives of the highest level terrace and indicate at least 2 phases of river rejuvenation and minor degradation.

Downstream from Locality 4 (Localities 5 - 7), a marked decrease in the overall framework clast and diamond size is observed and there is an increase in channel gravel over bar gravel. Reactivation (uplift 
and nick point development) along the thrust faults at Localities 9 and 12 caused the river to cut down sharply, producing a barren reach (between Localities 8 and 10) and inducing the capture of the paleo São Francisco river (which previously flowed to the SE from Locality 8). This event gave rise to a depositional phase further downstream of today's reach between Localities 10 and 11 . The economic potential of the sediments located between sample Localities 10 and 11 is rather limited as reflected in the diamond size distribution and in the framework hosted within the channel gravel.

The original São Francisco river valley used to flow to the SE after bypassing Locality 8 . The gravel deposits observed at Locality 13 are characterized exclusively by normally graded channel fill sequences with gravel bases fining upward to sand and silt. In addition, the average stone size in this area is very small. The economic diamond potential of this area is thus considered to be low. Further downstream (Locality 16), drilling results from the paleovalley prospect point out that the channel type deposits are still present but are of even smaller caliber. The economic diamond potential of this reach is virtually zero.

Reactivation along the NW-SE fault is clearly represented in the gravel thickness variation observed along the traverses D, J, I and E. The exposures at the localities 14 and 15 are particularly good. The fill of the most extreme southeastern portion of the paleodrainage (Locality 17) is comprised almost exclusively of silt, which represents the final response to downstream degradation of the former São Francisco river valley in favor of its capture and redirection along the east-west fault line valley. 


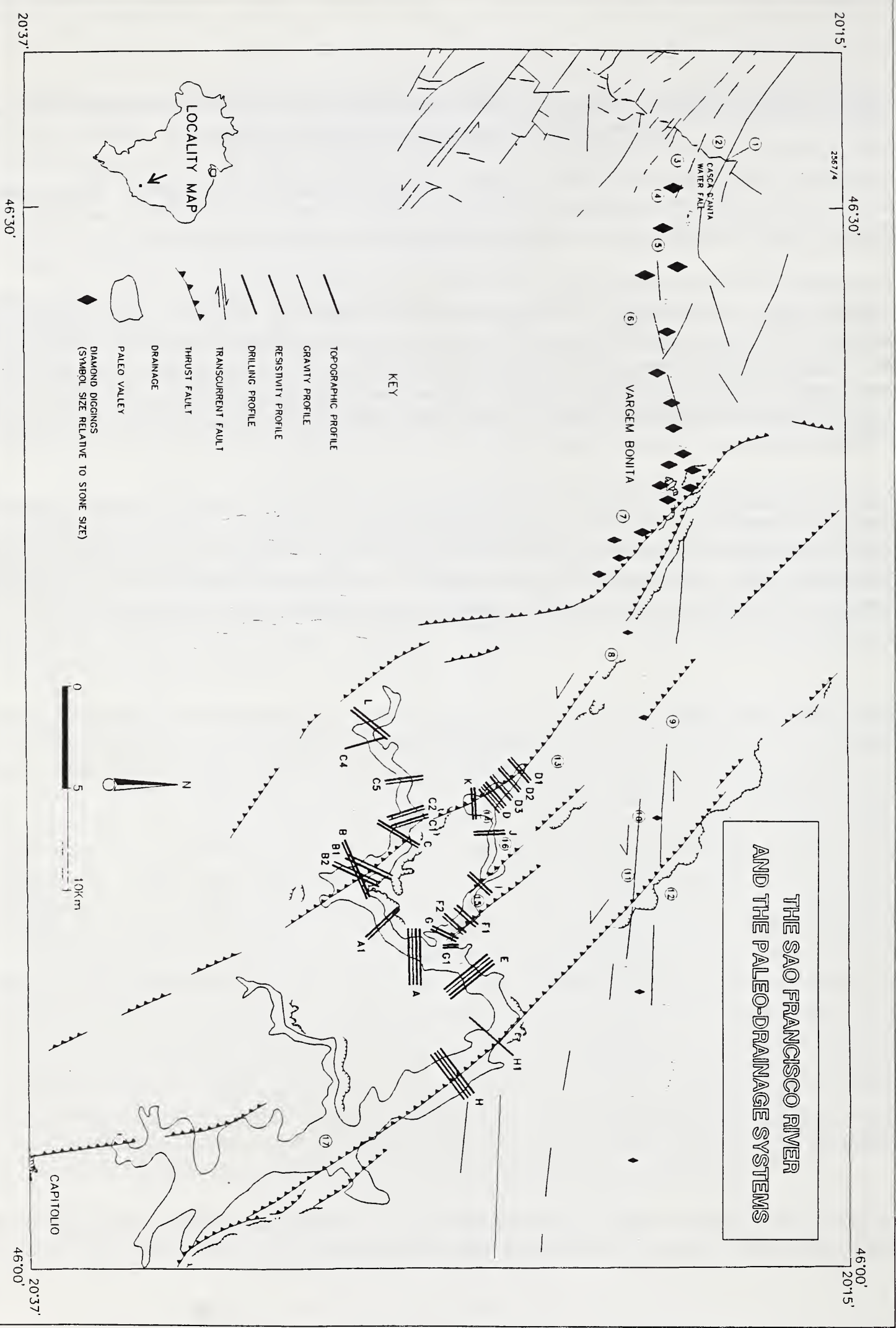

686 